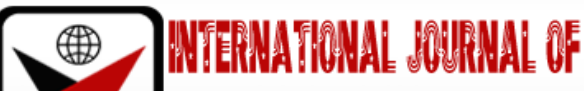

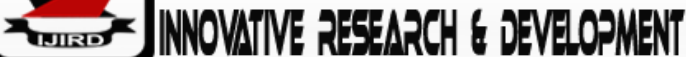

ISSN 2278-0211 (Online)

\section{Rural Poverty Alleviation Strategy in Nigeria}

\author{
Anthony Ikhide Osawe \\ Associate professor, Department of Geography and Environmental Management, \\ Ambrose Alli University, Ekpoma Edo State, Nigeria
}

\begin{abstract}
:
Poverty is a topical issue and will continue to remain so for years to come as rural poverty is deepening rural - urban divide in terms of welfare, with average income in rural areas keeps falling below the national poverty line. This paper describes the nature and evolution of poverty in Nigeria since independence. Poverty remains an attribute of vicious circle of low income, low level of savings or lack of it and low investment which lead to low level of employment and income. The growing poverty has resulted in various challenges and anti-social behaviours confronting the nation, including the now recurring economic recession, mal-nutrition, high infant mortality, insecurity, kidnapping, prostitution, unemployment, internet fraud, migration, ritual killings, banditry and terrorism. Efforts of Local, State National government to address poverty concerns through policy initiatives have failed to yield any appreciable result due to poor targeting, alien programme concept, corruption and poor governance. This paper recommends multidimensional approaches with the involvement of the stakeholders' concerned, international agencies and NonGovernmental Organisations (NGOs), efforts at job creation, improved human capita development and economic diversification.
\end{abstract}

Keywords: Rural poverty, Basic need, Extreme poverty, Relative poverty, empowerment

\section{Introduction}

In recent years, there have been widespread discussions on poverty at both national and international levels. Poverty is a social phenomenon in which a section of the society is not able to meet their basic necessities of life. This phenomenon is more pronounced in the third world countries where a substantial segment of a society is living at bare subsistence level.

Most societies have made attempt to define poverty, but all tend to focus on minimum or good life obtainable in the society. Therefore, the definition of poverty identifies the existence of social inequality and level of tolerance the sesocieties are prepared to accord the poor people. Poverty in the U.S. would be significantly being different from poverty in Nigeria or in India which are both third World countries. In India, the generally acceptable definition of poverty stressed on the minimum level of living, because their national plan was conscious of the difficulties in providing minimum quantum of basic needs for some future date and to go forth to talk about reasonable level of living would appear a wishful thinking (Mukerji, 1961). In their case, political considerations were weighed before accepting their definition. In Nigeria, our approach is a kind of wobbling and fumbling, living with 'nerve racking poverty, blood chilling squalor and degradation and agonising pestilence or hunger had been the lot of inhabitants' (Odom, 1999). We are yet to categorise poverty or give it a proper definition. The World Bank Sussex study on poverty (1969) covering sixty (60) countries, excluding Communist Chinaadopted two definitions of poverty: a) population that falls below poverty line which was defined byUS $\$ 50$ per capita and b) population that fall below poverty line which was defined by US\$75 per capita. The first definition which considered US $\$ 50$ per capita takes into account bare subsistence needs in terms of food. While the second definition which assumed US\$75 per capita include a little more such as clothing, some cost on housing, education and so on that made it less severe and reasonable.

Adopting that above definition to the Nigeria situation, it is worthwhile to further look into the absolute and relative poverty. Absolute in the sense of minimum requirement of grains, tubers, vegetable, milk, butter, clothing, or rather, the required calorie intake; then their price quotation converted into monetary terms from physical quantities. When the aggregate of all quantities is combined as number expressing per capita, consumer's expenditure is determined. Those within the population living below the calculated figure of expenditure/income are considered to be living below poverty line. According to Jazairy, Alamgir and Panuccio (1992) observed that 69 per cent of the total rural population lives in poverty. In absolute terms, Asia dominates the picture, with 633 million rural poor, 371 in India and China alone and 204 in Sub-Saharan Africa.

On the other hand, the identification, estimation of income distribution of various fragile group and compare the level of living of the 5 - 10 per cent with the bottom 5 - 10 per cent, this will lead us to relative poverty index. What constitute a defect here is that it indicates a relative position of different segment in income hierarchy. 
As it were, measuring poverty on the basis of per capita income is indicator applicable to when comparing the relative poverty position in Nigeria based on the assumption that per capita represents average position of members of the group being referred to. The adequacy of this approach is limited to identifying the relative position of the community because it conceals the vast variation in the actual income of different people within the community or nationality. There is the shortfall or lack of statistics of per capita income of group in a community or nationality to allow an intra-community or intra-nationality when compare, hence per capita could be misleading especially for rural people who are outside the mainstream of income distribution and who operate within the informal sector.

P. T. George (1979) noted that poverty is the relative deprivation arising from misdistribution of total income among different group. This has got to do with minimum subsistence level, in terms of money necessary to maintain the health and working efficiency of different groups. The poverty situation prevailing in Nigeria today may have drifted into a life of destitution as poverty index for both absolute and relative terms continue to increase, especially for those lower in the poverty ladder.

\begin{tabular}{|c|c|c|}
\hline Year & Rural Poverty (\%) & Urban Poverty (\%) \\
\hline 1980 & 28.3 & 17.2 \\
\hline 1985 & 51.4 & 37.8 \\
\hline 1992 & 46 & -- \\
\hline 1996 & 69.3 & $58 /$. \\
\hline
\end{tabular}

Table 1: per Cent age of Rural and Urban Poverty in Nigeria

Source: FOS (1980 - 1996)

The above table indicates that poverty level is higher in rural areas, while it moved from 28.3 per cent in 1980 to 51.4 per cent per cent in 1985, it experienced a decrease of About per cent in 1992 and recorded a quantum jump again in 1996 to 69.3 per cent. It was further observed from the report that $4 / 5$ of households having 20 or more persons were in poverty.

So, the cost-of-living index is necessary to identify category or group of people who do not have sufficient income to provide for a decent living condition. Rural people are afflicted by absolute poverty that does not fit into the frame of relative poverty index; i.e., the people's actual standard of living that consider food, shelter, and clothing including issues like sanitation, health, recreation and education. In this entire sphere, what exists is a picture of inadequacies and deficiencies in the provision of the above indicators in both rural and urban areas. This is why we have to avoid arbitrariness by linking poverty with social, economic and political respectability and development in each country.

\section{Poverty in Nigeria}

Poverty is deep rooted in Nigeria with its features more structural and multi-dimensional, which covers a range of critical deprivations perpetrated by the heirs of the Nigerian nationalism, Sir Herbert Heelas Macaulay, who denied himself of all opportunities to acquire wealth and invest in the nationalistic struggle for an emergent glorious Nigeria. When he died 1946 on tour of the country in Kano, he summoned his successors and spoke his last words 'when the new Nigeria comes, tell them for their tomorrow, we gave our today'. He breathed his last. (https: kwekudee trip down memory lane.blogspot.org. Five decades after independence, these heirs, have taken the tomorrow of Nigeria yesterday such that all characteristics of poverty, lack of income, human deprivation, physiological deprivation human rights deprivation, and social

Nigerian deprivations have come to stay. Poverty as cited by Aderonmu (2010) was defined as lack of command over basic consumption needs, having inadequate level of consumption, (Alujo, 2003), and inability for a person to attain a minimum standard of living and high status in a society (World Bank Report, 1990).

The Study conducted by the owned Federal Office of Statistics (FOS) showed that 'the number of people living below poverty line increased from 43 per cent of the population in 1992 to over 65 per cent in 1997; and 'The number of absolute poor from the figure of 18 million to 68 million between 1980 and 1996. This has manifested the fact that 'poor economic management hurt the poor most'. In recent years, Nigeria has continued to move down the line of poorest countries, even to become the poverty capital of the world. That the number of impoverished Nigerians according to Sahara Reporter (2019) was estimated to be 91.8 million are extremely poor. This was exactly where it was said by'the World poverty Clock' (https://www.worlddata.io.world.org) that had namedNigeria the poverty capital of the World with statistic showing 87 million people live in extreme poverty; 'that four million Nigerians joined The Poverty Club' between June 2018 and June 2019.

According to the World Bank, a person can be said to be living in extreme poverty if they live below the poverty line of US $\$ 1.90$ which translates to N693.5 per day. The above figure constitutes 46.5 percent of Nigeria's population which is approximated at $197,686,877$, sometimes rounded up to $200,000,000$. This goes tosay that more than half of Nigeria's population live on less than a dollar (N360) a day.

Today, the direct effect of poverty on our social economy is manifested in the daily occurrence of different antisocial behaviours such as corruption, arm robbery, kidnapping, prostitution, high rate of unemployment, especially among youth, advance fee fraud (419), mal-nutrition, high infant mortality - one of the highest in the World, short life expectancy 52 -years, which is 5-years below WHO's minimum, Nigerians are living in Squalor, shanties, shackle. The most disturbing of the Nigerian human development issue contained in the UNDP-HDR (2008) 'that as many as 33.8 per cent of Nigerian's population are not expected to survive to the age of 40 -years. 
The above depict the Nigerian poverty scenario where over 91.8 million are extremely poor. This figure constitutes 46.5 per cent of Nigeria's population. This is evident that poverty has increased in Nigeria to a tragic level in recent years. The household survey data by Nigeria owned National Bureau of Statistics (NBS) 1980 - 2010, collected under the National Integrated Survey of Households (NISH), show as follow:

\begin{tabular}{|c|c|c|c|}
\hline \multirow{2}{*}{ Year of Survey } & $\begin{array}{c}\text { Sample Size } \\
\text { (No of Households) }\end{array}$ & $\begin{array}{c}\text { Households } \\
\text { (Million) }\end{array}$ & $\begin{array}{c}\text { Population Size } \\
\text { (Million) }\end{array}$ \\
\hline 1980 & 10,280 & 17.3 & 73.69 \\
\hline 1985 & 9,317 & 18.80 & 74.7 \\
\hline 1992 & 9,697 & 20.7 & 99.2 \\
\hline 1996 & 14,395 & 24.5 & 120 \\
\hline 2004 & 19,158 & 26.6 & 126 \\
\hline 2010 & 34,799 & 38.3 & 159.7 \\
\hline
\end{tabular}

Table 2: National Integrated Survey of Households (NISH)

Source: Household Survey of Nigeria 1980 -2010 from NBS and

Population Data from World Bank

The survey is the national consumer survey (NCS) fielded in 1980, 1985, 1992; The 2003/2004 Nigeria living standard survey (NLSS); and the most recent, the 2009/2010 Harmonized Nigeria Living Standard Survey (HNLSS). These surveys were conducted by the National Bureau of Statistics, Nigeria (NBS), and formerly Federal office of Statistics (FOS), in collaboration with the World Bank, United Kingdom's Department of International Development (DFID), UNICEF and the European Union (EU).

\begin{tabular}{|c|c|c|c|c|c|}
\hline Year & $\begin{array}{c}\text { Life Expectancy } \\
\text { at Birth }\end{array}$ & $\begin{array}{c}\text { Expected Year } \\
\text { of Schooling }\end{array}$ & $\begin{array}{c}\text { Mean Year of } \\
\text { Schooling }\end{array}$ & $\begin{array}{c}\text { GNI per Capita } \\
\text { (2011 PPPS) }\end{array}$ & HDI Value \\
\hline 1990 & 45.9 & 6.7 & & 3.221 & \\
\hline 1995 & 45.9 & 7.2 & & 2.872 & \\
\hline 2000 & 46.3 & 8.0 & & 2.828 & \\
\hline 2005 & 48.3 & 9.0 & 5.2 & 3.819 & 0.467 \\
\hline 2010 & 50.9 & 8.4 & 5.2 & 4.793 & 0.484 \\
\hline 2015 & 53.1 & 9.7 & 6.2 & 5.540 & 0.527 \\
\hline 2016 & 53.5 & 9.5 & 6.3 & 5.336 & 0.528 \\
\hline 2017 & 54.0 & 9.7 & 6.5 & 5.203 & 0.533 \\
\hline 2018 & 54.3 & 9.7 & 6.5 & 5.086 & 0.534 \\
\hline
\end{tabular}

Table 3: Nigeria's HDI Trends Based on Consistent Time Series Data and New Goalpost Source: Human Development Report 2019

Inequality in human development hurt societies and tends to weaken social cohesion and people trust in government, institutions and on individuals. The economy is also hurt thereby wastefully preventing people from reaching their full potentials both at work and in life. It is made harder for political decisions to reflect the aspirations of the whole society and to protect our planet as those pulling ahead of flex their power to shape decisions primarily in their interests. Inequalities in human development are a defining bottleneck in achieving the 2030 Agenda for Sustainable Development.

Between 2005 and 2018, Nigeria 's HDI value has increased from 0.467 to 0.534 , an increase of about 14.4 per cent, as shown in the above table 3 which reviews Nigeria progress in each of the HDI indicator. One could see that between 1990 and 2018, Nigeria life expectancy at birth increased by 8.4 per annum. Mean year of school have increased by 1.2 years and expected year of schooling increased by 3.0 years, and Nigeria's GNI per capita increased by about 57.9 per cent between 1990 and 2018 (Nigeria Human Development Report, 201 Okhiria,\&Obadeyi, 2015).

\section{Poverty Line in Nigeria situation}

According to ZuhumnanDapel (2018) Nigeria has no official poverty line, attempt to measure poverty in the country use different lines. A measure of absolute poverty, Sulharshan, Ngwafon\&Saji (2002), FOS, (1999) and Ayanwu $(2005,2010)$ used two-third of mean consumption per capita expenditure in the 1985 survey, i.e., N395.4 per person per annum in 1985 prices. This became equivalent to N5, 795.36 per person per month in the month of July 2016 prices. The line was later adjusted, using the consumer price index (CPI) for estimating poverty later in the year, as was in the case with the 1980 - 1996 poverty profile released by FOS.

On the other hand, the 2004- 2010 poverty Report of the NBS derived and adopted other higher lines for measuring absolute poverty in Nigeria. In 2004, a per year line of N30,128, equivalent to N7,804.72 per person per month at 2016 price in July, and in 2010, an annual line of N54,401.16 per year or N7,406.70 at July 2016 prices. In real terms, the line adopted in 2004 was higher than that of 2010. On the 2010 absolute poverty line, the NBS decided to use 3000 calories as expected minimum calorific in take for average Nigerian, which was a recommendation from a Nutritionist consultant, who thought this as reasonable benchmark for Nigeria with its average food basket. Based on the above, the 
NBS calculated a minimum annual expenditure required for 2004 for an adult as equivalent to N21, 743 on food to achieve 2,900 calories per person per day. It is this expenditure on food that constitutes the threshold for extreme poverty.

\section{Literacy}

The Digest of Educational Statistics in Nigeria Published by Federal Ministry of Education concerning literacy of Nigerians between the ages of $15-24$ in 2017 put the female young adult literacy rate 59.3 per cent while that of male is70.9 per cent, while the national literacy rate in Nigeria remains at 65.1 percent. In a recent UNESCO definition of literacy, it defined literate person as 'as one who can read and write with understanding, both read and write a short simple statement on his/her everyday life, and an illiterate person as one who cannot with understanding both read and write short simple statement in his/her daily life.

The This Day (Lagos) of 1st August, 2019 wrote that the National Commission for Mass Literacy Adult and Nonformal Education (NMEC) said recently that 35 per cent of the national adult population was illiterate, and it had remained high because every effort that have been put forward to improve the poor situation has refused to impact positively in the programme. Looking at the outlay and corresponding efforts the nation has committed to various mass literacy programmes, the Universal Primary Education (UPE) scheme inclusive, which was launched with so much fanfare some 33 years ago (1976) it is disturbing and worrisome that as much as 33 per cent of the population are self-indulgent in illiteracy. NMEC considered this figure shameful in the $21^{\text {st }}$ century for a country to have such number of illiterates. More disturbing is that the country is not doing enough to improve the literacy figures, and this does not give cause for cheers when juxtaposed with the literacy figures of other developing countries when considered against the background that education is the engine for national development.

Literacy rate in countries like Cuba, Poland, and Estonia with as high as 99.8 per cent while countries like Barbados, Latvia and Slovenia have 99.7 per cent (UNDP, 2007/2008). The same report put Nigeria literacy rate at 69.1 per cent this high level of illiteracy rate could account for the low level of development in Nigeria. This is because the growth and development of any nation depend largely on the quantity and quality of education, skills and training of every facet and segment of the population.

There have always been concerted efforts by the Federal government and some southern state that have invested to boost literacy levels by setting up a number of strategic institutions, commission and centre for learning across the nation, while others are paying mere lip services to the chagrin and burden detrimental to functional literacy.

\section{Development in Health and Education}

The National Population Commission (2012) said that a total of 67 per cent of the nation population resides in rural areas and 34 per cent live in urban centres.

Just as it affects literacy, so it is for infant/child mortality rate and education. Again, statistics showed that between 1960 and 1995, the number of primary schools rose by 1,000 per cent and enrolment increased by fie folds. Currently, there are about 42,242primary schools with 16,796,078pupils in government own schoolsand 1,965,517 in private school, despite these, over 15 per cent of rural Nigeria has no educational facilities. Within the same period, the number of secondary schools also increased by about 500 per cent while enrolment rose by over 22 times. There are 7,104 secondary schools with 4, 488,981 students. The same situation prevails in the tertiary institutions. There are forty-six (46) Polytechnics with over 150,000 students, sixty-four colleges of education with almost 100,000students and yet the financial allocation by the Federal Government to education sector has remained stagnant, in the same way the number of teachers has not increased either. Point here is that education system has virtually collapsed in a situation where primary school enrolment (age $6-11^{\prime}$ ) averaged 65.5 per cent in 1996 with a clear variation across the thirty-six (36) six state being very wide - AbiaState recorded 96.2 per cent (the highest) and Jigawa state had 17.1 per cent of primary school age population at school. In addressing poverty and related health, acquisition of knowledge and skills, empirical evidence shows that there is a steady decline in the percentage of the poor and their educational levels. These are aspects of the survey by FOS has recorded a decrease from 53 per cent for household where heads have no education to 30 per cent for household where heads had post-secondary education. Only 4 per cent of all heads of households had any education at all, 21 per cent had only primary school education and 14 per cent had up to secondary school education and 5 per cent had post-secondary education.

Health situation did not fare better despite efforts of the various UN agencies in this sector, UNICEF, UNFPA, etc. Like education, they both hold the key to alleviation and eventual eradication of poverty. This sector suffers the problem of neglect, inadequate investment, poor strategy and even poor implementation have continue to hunt human poverty, Since the 1980s, Nigeria HDI of 41.6 is largely due to i) deprivation in education, ii) knowledge and iii) deprivation in socioeconomic provisioning; principally, in public health and portable water. Despite the fact that Nigeria has accepted obligation from various international conferences such as 'Education for all, and Reduction in Adult Literacy, Universal Access to Safe Drinking Water, Universal Access to Primary Health Care. All these are aimed at attaining a considerable reduction in under -5 mortality rate and infant mortality rate to something close to WHO's target, and when this done, the country would have improved its rating from 54 among the poorest nations according to human poverty index.

\section{Multidimensional Poverty in Nigerian}

UNDP's Report of $11^{\text {th }}$ July 2019 reveals that in Nigeria, even though the proportion of people who are multi dimensionally poor remained constant at just over 50 per cent for the past decade (up to 2017). But the actual number of people who are multidimensional poor increased from 86 million to 98 million over the same period. The multidimensional Poverty Index (MDI) is the new method of measuring poverty as currently defined by the United Nation 
Systems (UNDP). It looks beyond income to understand how people experience poverty in multiple and simultaneous ways. It recognizes how people are being left behind across three key dimensions, namely: health, education and standard of living, it comprises 10 indicators. So, people who experience deprivation in at least one third of the weighted indicators falls into the category of multidimensional poor.

The National multidimensional Poverty Index for Nigeria (NG-MPI) was actually focused on advancing development in the North East. This work was commissioned by UNDP Nigeria and the National Bureau of Statistics` (NB). The Ni9zgerian MPI has 11 indicators that cover 4 equally weighted dimensions of Education, Health, Living Standard and one could add Unemployment. This was computed at sub-national level using data from the 2017 Human Development indices survey which covered urban and rural areas in all the 36 states and the Federal Capital Territory.

To calculate the Ng-MPI, a house hold is to be considered multidimensional poor if it is deprived of deprived in more than certain percentage of the weighted indicator. For Nigeria, at the national level, the share of multidimensional poor people is 54 per cent with the average intensity of deprivation standing at 42 per cent.

\begin{tabular}{|c|c|c|c|}
\hline Dimension of Poverty & Indicator & Deprived If Living in the Household Where... & Weight \\
\hline \multirow[t]{2}{*}{ Health } & Nutrition & $\begin{array}{l}\text { An adult under } 70 \text { years of age or a child is } \\
\text { undernourished }\end{array}$ & $1 / 6$ \\
\hline & Child mortality & $\begin{array}{l}\text { Any child under the age of } 18 \text { years has died in } \\
\text { the five years preceding the survey }\end{array}$ & $1 / 6$ \\
\hline \multirow[t]{2}{*}{ Education } & $\begin{array}{l}\text { Years of } \\
\text { schooling }\end{array}$ & $\begin{array}{l}\text { No household member aged 10years or older has } \\
\text { completed six years of schooling. }\end{array}$ & $1 / 6$ \\
\hline & $\begin{array}{l}\text { School } \\
\text { attendance }\end{array}$ & $\begin{array}{l}\text { Any school-aged child is not attending school up } \\
\text { to the age at which he/she would complete class } \\
8\end{array}$ & $1 / 6$ \\
\hline \multirow[t]{6}{*}{ Standard of living } & Cooking Fuel & $\begin{array}{l}\text { The household cook with dung, wood, charcoal } \\
\text { or coal }\end{array}$ & $1 / 18$ \\
\hline & Sanitation & $\begin{array}{c}\text { The household sanitation facility is not improved } \\
\text { (according to SDG guidelines) or it is improved } \\
\text { but shared with others households }\end{array}$ & $1 / 18$ \\
\hline & Drinking Water & $\begin{array}{l}\text { The household does not have access to improved } \\
\text { drinking water (according to SDG guidelines) or } \\
\text { safe drinking water is at least } 30 \text { minutes' walk } \\
\text { from home, round trip. }\end{array}$ & $1 / 18$ \\
\hline & Electricity & The household has no electricity & $1 / 18$ \\
\hline & Housing & $\begin{array}{l}\text { Housing materials for at least one of the roof, } \\
\text { wall and floor are inadequate the floor is of } \\
\text { natural materials and/ or the roof and/or walls } \\
\text { are of natural or rudimentary materials. }\end{array}$ & $1 / 18$ \\
\hline & Assets & $\begin{array}{l}\text { The house hold does not own more than one of } \\
\text { these assets: radio, TV, Telephone, Computer, } \\
\text { animal cart, bicycle, motorbike or refrigerator } \\
\text { and does not own a car or truck }\end{array}$ & $1 / 18$ \\
\hline
\end{tabular}

Table 4: The 2019 Global Multidimensional Poverty Index Source: UNDP 2019 Multidimensional Poverty Index

The result of this study has indicated a high incidence of poverty across the North with very poor stated having 80 per cent of their population classified as multidimensional poor (https://mppn.org).

\section{Causes of Poverty}

Poverty is an attribute of vicious cycle of low income, low level of saving or lack of it, and low investment, which leads to low level of employment and income. Considering the level of capacity under underutilisation and under employment in our economic system, the cycle can be widened to accommodate low productivity, market imperfection, traditional/indigenous technology and know-how, over population and concentration of economic powers, mostly in the hands of corrupt and fraudulent people. In an attempt to identify the poor, both the unemployed and under employed, all standout as a group. Different factors are responsible from international, national and local perspectives; so also, are the social, economic political and cultural factors exercising their various influence at national and local levels. On the other hand, they could be listed as: Stage of economic and social development; low productivity; market imperfection; physical or environmental degradation structural shift in the economy; inadequate commitment to programme implementation and corruption. 


\section{Poverty Alleviation Programme in Nigeria}

One of the programmes aimed at community development, employment generation and agricultural development for export and cash crops was the Farm Settlement which was introduced in 1960. But by 1972, the government interest weaned and the scheme collapsed and attention was shifted attention to a new programme, National Accelerated Food Production Project. It was among other things aimed at disseminating for adaptation of new findings in agricultural research to farmers. In the following year (1973), Agricultural Development Project (ADP), a project supported World Bank was initiated to provide credit facilities, promote agriculture and integrated rural development. This project was short lived and by 1976, Operation Feed the Nation (OFN) was birthed towards self-reliance. The programme indeed created awareness to increase food production without any appreciable increase in agricultural production (Taiwo and Agwu, 2016). Rural Banking Scheme was introduced in 1977 to bring Banking closer to the people. In 1979, came the Shagari administration, which in 1980 introduced the Green Revolution Programme (GRP) and the River Basin Development Authority (RBDA).

Statistics relating to Nigeria's poverty scenario are completely dismal; this is more disturbing when viewed against the background that the period between 1986 and 1997 when poverty situation deteriorated and got worsened, experienced proliferation of poverty alleviation institutions with multiple infrastructures, staff and finances which have been difficult to justify. Specifically, programmes like the Directorate of Food, Road and Rural Infrastructure (DFRRI), Better Life For Rural Women (BLFRW), Were aimed at improving the lots of rural people, while others like National Directorate of Employment (NDE), Mass Mobilisation for Social and Economic Recovery (MAMSER), National Land Development Authority (NALDA, National Economic Reconstruction Funds (NERFUND, Family Support Programme (FSP), Peoples' Bank of Nigeria (PBN), Family Economic Adjustment Programme (FEAP), Oil and Mineral Producing Development Commission (OMPADEC) and Nigerian Social Insurance Trust Fund (NSITF).

DFRRI was established in 1986 to develop rural areas in phases; in its first phase, it claimed to have provided 250 communities with portable water and another claim of portable water to 500 communities in 1992 . Investigation by government own team were to reveal that the claim by the agency were either false or where at all such project exists, they were non-functional.

Similarly, in 1987, the NDE was established through Decree 24 of 1989, as a specialised institution to create jobs. After 12 years of programme in Open Apprenticeship for Vocational Training, Agricultural Programme for Arable and Livestock, Micro-Enterprise and Special Public Work, the agency succeeded to prone down unemployment among graduates, School Leavers, etc. by 3.1 per cent as at 1992.While this programme had a serious loan default problem; under funding was also a serious problem as the government attentions were directed towards the First lady's pet project in the last years of that administration. FEAP received N7.3 billion as take-off grant though the office of the First Lady was unconstitutional. In 1998, the budget FEAP received was N3.3 billion while NDE received N200 million (FGN/NPC, 1995). Others were People Bank Programme (PBN), to extend credit services to the poor; Petroleum Trust Fund (PTF), to rehabilitate infrastructures -Schools, roads, hospitals, water and agriculture; The Oil and Mineral Producing Areas Committee (OMPADEC), to develop the oil producing areas; Nomadic Education, to raise the literacy level among the nomadic group; River Basin Development Authorities (RBDA) to develop the basins of the major rivers in the country.

The Nigerian fourth Republic was ushered in 1999 with a lot of fans- fare when the National Poverty Eradication Programme (NAPEP). This programme was aimed at eradicating absolute poverty in Nigeria. The programme is complemented by the National Poverty Eradication Council (NAPEC) with a responsibility to coordinate poverty relayed activities among Ministries, Parastatals and Agencies. Under NAPEP, there were four institutions concerned with poverty related issues, they are: Youths Empowerment Scheme (YES), Rural Infrastructural Development Scheme (RIDS), Social Welfare Scheme (SOWESS) and National Resource Development Conservative Scheme (NRDCS). With the above institutions in place, NAPEC has adopted the following poverty alleviation Programme:

- Trade and Payment liberalisation

- Tariff reform and rationalisation for the promotion of industrial diversification

- Deregulation and greater reliance on market forces particularly in the downstream activities of the crude oil industries

- Adoption of appropriate pricing policy of all commodities and

- Adoption of method to stimulate production and broaden the supply base of the economy

- $\quad$ Seven Point Agenda (SPA);

- Nigeria Vision 20:2020',

- $\quad$ N-Power and

- Trader-money,

The above myriad of programmes, have been established at one point or the other in Nigeria aimed at alleviating incidence of poverty. On records the government seems to have demonstrated significant efforts toward the socioeconomic growth of the nation. Still, Nigeria remains the poverty capital of the world (WPC, 2019).

From the above, it is obvious that 'government concept of rural development or poverty alleviation programme' have only been catapulted to the level of development politics and corruption, and has continue to remain a dream. The gulf has continued to grow wider as no direct or indirect benefits accrue to the poorest among the poor for whom rural development is meant to serve' (Osawe, 1984). The indices that have been reflected in previous pages are direct outcomes of successive governments' programmes of actions in Nigeria. According to the World Bank Technical Paper No. 336 (1975), 'the root of the limited achievement in local development in Nigeria lie not in the lack of effective and dynamic institution at the local levels as much as the inappropriate, unproductive and functionalism of the relationships between communities and the formal institution of state'. 
It has long been proved that the top-down policy approach has failed to elicit people's participation through which the civil society can exert influence over public decisions and open that public process to scrutiny, 'in this manner participatory development is fans directly linked to State accountability, empowerment of local group and transparency in decision maki9ng' (Mitlin\& Thomson, 1995). The major constraints to programme implementation remain faulty conceptualisation, inappropriate to the needs of the communities and the beneficiaries, anti-poor structure as they were aimed at creating jobs for the 'boys'. Despite the pretence of pious sentiment of successive governments to poverty alleviation, the number of the poor continues to swell as it currently stood at 91.8 million people in 2019.

Community Development (CD) approaches to rural indeed helped to awaken the consciousness of the local communities when it was launched, especially in the South part of the country. This is evidenced by the number of community sponsored schools, town Halls, dispensary, health centres, electricity projects, bore-holes, and pie-borne water. As it were, much was expected to be achieved at the communal level, however, government functionaries who could have induce be inducing the people to new orientation either became jaded or fall in short supply.

\section{Role of Non-Governmental Organisation (NGO)}

Across the developing world, most states have limited finances, and pierce by poor governance and corruption that failed to lead to inclusive development for all of their citizens. Arising from the background, alternative forms of development have been pursued, and since the 1980s, nongovernmental organisations (NGOs) have been increasingly advocated as a means through which the gulf between citizens' needs and existing services can be bridged (Turner, McCourt and Hulme,2013). This becomes the panacea where states cannot provide sufficient goods, services or enabling environments that help citizens in securing livelihoods, or where the disadvantaged groups are excluded from existing state institutions, alternative channels of service provision and/or holding governments to account must be found. It is into this gap that NGOs have neatly fitted.

The apparent failures of state-led development approaches throughout the 1970s and 1980s stimulated interest in NGOs as a development alternative, with capacity to offer innovative and people-centred approaches to service delivery, advocacy and empowerment. Overtime, NGOs and their position within the development sector have risen considerably; the classification of NGOs remains difficult (Vakil 1997). Emerging from long-term traditions of philanthropy and self-help (Lewis and Kanji, 2009), NGOs vary widely in their origin and levels of formality.

The Civil society or voluntary organisations are active in rural regeneration, largely in neglected, inaccessible parts of the country. Before the mid -eighties, the missionaries were most prominent before the private voluntary organisation began to spring up. These voluntary organisations that are engaged in social development work are close to the people and they have the capacity to mobilise and motivate community for their participation in development programme in the sectors they have carved a niche for themselves (Osawe, 2004). The NGOs play different roles, some as catalyst; others act as coordinating bodies or as institution delivering services directly to rural population; with their scope of operation ranging from international, national and or local level.

Having played a pioneering role in rural poverty alleviation over the last five to six decades, they have consistently demonstrated the quality of flexibility in service delivery, personal touch and closeness to target clientele. They have equally demonstrated significant capacity to initiate and experiment new programmes, stimulate community's interest with enough sensitivity to surmount difficult problems in a manner that cannot be adopted by the state. They are in the forefront in deploying strategies in micro-finance, enterprise development, small-scale business management, community project, agricultural extension, and input supply, agro-processing, networking and synergy building which enables them to attack problem of poverty. One of their most exciting approaches is the concept of Participatory Rural Appraisal (PRA) and Participatory Learning and Action (PLA) and REFLECT (Osawe, 2004; Chambers, 1992; 1995).

These approaches combined the elements of accountability, transparency, responsibility and empowerment. NGOs are building alliance to fight for social and economic justices; this is why NGOs in socio-economic development, human right, education, health, and environment work together to achieve sustainable development recognising the vicious nature of poverty which requires a multi-dimensional strategy. Gender issues, such as violence against women, oppressions, equality and rights of individuals are strategies that have evolved through a long process of consultations, dialogue and reflections amongst agencies with focused on poverty and the attendant social inequality and the delivery of basic services to empower communities that suffer unjust distribution of resources.

\section{Role of International Agencies}

The extent to which international agencies are involved in rural or socio-economic development are regulated by the nature of agreement entered into between the country and the agency concerned based on the Technical Cooperation Policy. During the Structural Adjustment programme (SAP) in 1986, mobilisation of external resources became a high priority of government. The first National Development Plan (1962 - 68) assigned a pivotal role to external development assistance in public sector. Up to 50 per cent of the resources were expected from bilateral and multi-lateral donor agencies. This approach was immediately ignored following the discovery and oil boom of the 1970s, to the extent that the second and the third National Development Plan paid less emphasis on external financing as' finance was no longer a major constraint' (NPC, 1995). But the economic policy since 1986 reemphasised the role of external development assistance in the adjustment and development process.

Agencies working under bilateral and multilateral agreement in Nigeria are the United Nations (UN) agencies, UNDP, UNICEF, UNIFEM, UNIDO, WHO, The World Bank, The European Union (EU), Department of International Development (DFID), United State Agency for International Development (USAID), the German Agencies and Embassies and High Commissions, etc. These agencies have the specific area of intervention and focus, which by extension help to 
alleviate poverty directly or indirectly through collaboration with government, agencies, Civil Society Organisations (NGOs) or Community Based Organisations (CBOs).

\section{Poverty Alleviation}

It is a statement of fact that both rural and urban poverty in Nigeria emerges out of long-established malaise in social and economic structure, screwed distribution of ownership of income and income yielding assets. These have remained the bane and drain of all poverty alleviation efforts over the years. To sustain any poverty alleviation efforts would require rectification to the growing unequal distribution of cumulative income yielding assets which have resulted from the continuance perpetration and intensification of the existing structure. Secondly, there exist the inter-connected vicious circle of affluence andpoverty. So, alleviation of poverty must go hand in hand with the removal of affluence through matching production with distribution as one determines the other. These two things must be taken separately because productive efficiency and distributive injustice are different independent variable of growth. There is need to alter the current approach to income distribution that remains a distortion to alleviation of poverty in rural areas, driven through the objective of increasing the production of wage -goods. Again, it has to be mentioned here that this decision is not economic but resides in the political domain which require a strong political will on the side of government to usher in some measures of institutional changes capable of redistribution of income and income yielding assets.

A look at other aspects of two requirements of poverty alleviation programmes are:

- Re-orientation of agricultural relations relative to fragmentation of holdings, studies have revealed that 'there is no technological barrier to a small holding achieving high productivity per unit of land; Some of the highest yield in the world, of rice in Japan, and cotton in Egypt, has been obtained in an agriculture characterised by small holdings' (India Planning Commission, 1973). What the farmers require is the resource base and credit support and better inputs such that can lift the poor peasantry out of poverty.

- There is no poverty alleviation programme that can succeed in an economy plagued by inflation and spirally rise in price. 'Inflation by its very nature accentuates inequalities, into income of the poor classes and thus leads todeterioration in their economic condition' (Datt\&Sundharam, 1981). Therefore, in designing a poverty alleviation programme, attention must be given to a policy to mop up the surpluses with the elite class (finance house, merchants and capitalist) etc. In fact, surpluses in form of black money to avoid such money being misdirected into channels of conspicuous consumption. Again, this requires a political will.

Often, as were in 1999, the then Vice President AtikuAbubarkar was quoted to have said that the Federal Government would create 5 million jobs (The Guardian Sptember7, 1999 front page). It was then a welcome news as providing employment and raising productivity of low level of employment is a sure way to move a vast majority living below poverty line to rise above it. However, this has remained rhetoric as successive government has continued to make similar promises that have remained elusive. Instead, monumental waste of public funds on half-baked anti-poverty programme of paste, the inauguration of a review panel chaired by Alhaji Ahmed Jordal by the Obasanjor/Abubarkar administration to review poverty alleviation institutions outcomes has not made any difference.

\section{Conclusion}

The menace of poverty from every aspect can be handled through multidimensional approaches, with active participation of the international community playing active role where necessary as poverty is already bearing its brunt on the absolute poor. It will be appropriate to deploy some policy dimensions required to domesticate and alleviate poverty effectively:The first is to empower the poor. This can be made possible through the right kind of education. Education remains one great weapon that can be used to battle the threat of poverty. With educated people in place, entrepreneurship and skill development can be handy as essential tools for poverty to be eradicated in the country.

Microfinance institution has demonstrated significantly that young people with entrepreneurial skills can be empowered through soft loans, sponsored and encouraged to develop such ideas while efforts should be made to showcase them and their work for multiplier effect.

There should be deliberate policy strategy is to create jobs. This however, should be done both directly and indirectly by governments at all levels. Indirect employment generation has to do with policies that make the environment conducive for investors and firms to thrive.

Our economy is over dependent on oil and this is overdue for urgent diversification. Oil is no longer fashionable and does not have future any prospect for reliance. The COVID 19 experience and the demand for oil is handy as nations are already developing alternatives to oil. Electric cars are now been developed. This is the period to actively and aggressively diversify the economy. Moreover, attempt should be made to reduce drastically the wide income and gender gaps in the country.

Incidence of poverty is higher among female headed family in Nigeria; this has continued to fuel poverty. Until something drastic is done to reduce the inequality, the level of poverty will keep increasing.

So far, our economic growth does not reflect on the aspiration of the poor, it must be allowed to trickledown to the poor.

This can be achieved through policies in sectors that provide more employment for the poor; or developed certain social safety net address the needs of the poor and the vulnerable in society.

The national decay in existing infrastructures is in a sorry state and need urgent attention. In fact, the situation of roads and power supply in Nigeria is worrisome. For example, major Federal, State and local roads are in complete state of disrepair, while the nation's average power supply is 3,851 megawatts (MW) for a population of about 191 million people compare to a country such as South Africa, which generates approximately 51,309 MW electricity on average for her popul6-ation of around 57 million. 
The Nigerian Government policies are among the best in the World. But inexperienced technocrats appointed to manage the economy without genuine commitment to fighting corruption, this coupled with high cost of governance are the bane and poverty raiser in Nigeria.

The money misappropriated can be spent on projects and infrastructures that benefit the poor and transform the economy. The need to develop human capital and direct their energy to small and medium scale enterprises should be considered a priority, while encouraging the informal sector to develop and not harassed for purpose of revenue generation should be addressed. Finally, this paper suggested investment in education that will help the poor to control their population.

\section{References}

i. Adedeji, A. (1999) Imperative of Forming a National Grand Alliance to Combat Human Poverty, Social Pauperization and Social Degradation in Nigeria. Ilorin August 10.

ii. Aderonmu, J. A. (2010) Local Government and Poverty Eradication in Rural Nigeria. Canadian Social Science, 6 (5), $200-208)$.

iii. Agwu, M. E. \&Kadiri, K. I. (2014)Analysis of Critical Strategic Factors for Successful Implementation of Poverty Alleviation Programme in Nigeria. International Journal of Computational Engineering and Management, 17 (1), $1-9$.

iv. Aluko, M. A.O. (2003) Strategy for Poverty Reduction in Nigeria. Journal of Social Science, Vol. 7 No4, pp255 266.

v. Anyanwu, J. C. (2010) Rural Poverty in Nigeria: A Gendered Analysis. African Statistical Journal, 11 (11), 38 61.

vi. Anyanwu, J. C. (2005) Rural Poverty in Nigeria: Profile, Determinants and Exit Paths. African Development Review, 17 (5) 455 -460.

vii. Chambers, R. (1995) Learning from the Poor: Participatory Rural Appraisal and Participatory Learning and Action. Institute of Environment and Development (IEDS), Brighton.

viii. Chambers, R. (1992) Rural Appraisal, Rapid, Relax and Participatory. IDS Discussion Paper 311, Institute of Development Studies, Brighton.

ix. Datt, R. \&Sundharam, K. P. M. (1981) India Economy. University of Bombay.

X. Ebosele, M. \& Shola, F. (1999). The Guardian News Paper, Friday, August27, p15.

xi. Federal Republic of Nigeria /National Planning Commission/, (1995). Technical Cooperation Policy for Nigeria - NPC-Lagos.

xii. Federal Office of Statistics (FOS)/World Bank (WB) (1998). Poverty Assessment Report -1980 - 1996.

xiii. FOS (1999). Poverty Profile for Nigeria: A Statistical Analysis of 1996/97 National Consumer Survey (reference to 1980, 1985, and 1992).

xiv. George, P. T. (1981). Poverty and Unemployment, in Rural development in, Some Facets, NIRD- Hyderabad, pp72.

xv. HerbertMacaulay: The Founder of Nigerian Nationalism and the Ghandi of West Africa. (https: kwekudeetripdownmemorylane.blogspot.org. November 12, 2013.

xvi. India Planning Commission (1973). Approach to $5^{\text {th }}$ Plan $1974-1979$, p.5.

xvii. Jazaiyry, I. M., Alamgir, M., \&Panuccio, T. (1992). "The State of Rural Poverty. An Inquiry into its Causes and Consequences'. New York, New York University Press/ IFAD.

xviii. Lewis, D., and N. Kanji, 2009, Non-Governmental Organizations and Development, Abingdon, UK: Routledge.

xix. Mitlin, D. \& Thomson, J. (1995). Participatory Approaches in Urban Areas: Strengthening Civil Society or Reinforcing the Status quo? Environment and Urbanisation. Vol. 7 N0. 1pp233.

xx. Mukerji, B. (1961). Community Development in India, Orient Longmans, Bombay.

xxi. NBS, Annual Socio-Economic Report. Abstract Contains in Nigeria: Unemployment Report 2011. Retrieved $21 / 03 / 2020$.

xxii. Okhiria, O. A. \&Obadeyi, J. A. (2015). Poverty, An African Epidemic: Empirical Evidence of Nigeria. Developing Countries Studies, Vol 5 N06, pp 29 - 39.

xxiii. Osawe, A. I. (2004). Spatial Perspectives on the Impact of Non-Governmental Organisations (NGOs) on Poverty Alleviation in the Rural Areas of South -Western Nigeria. An Unpublished Thesis Submitted to the Graduate School, Ambrose Alli University, Ekpoma in Partial Fulfilment for the Award of Doctor of Philosophy in the Department of Geography and Regional Planning. Unpublished.

xxiv. Osawe, A. I. (1984). Socio-Economic Impact of River-Basin Project on Rural Development. Unpublished Master's Dissertation, Submitted to Department of Rural Studies, South Gujarat University, Surat India, pp 170.

xxv. Sahara Reporter (2019). 91.8 million Nigerians are Extremely Poor. http://sahara Reporter.org New York. Retrieved 21/03/2021.

xxvi. Sulharshan, Ngwafon, Saji (2002). Poverty in a Wealthy Economy: The case of Nigeria Vol. 2. International Monetary Fund.

xxvii. Taiwo, J. N. And Agwu, M. E. (2016). Problems and Prospects of Poverty Alleviation in Nigeria. International Journal of Business and Management Review, European Centre for Research and Training, UK, Vol. 4 No 6 pp 18-30. www.eujournal.org Retrieved 22/03/2021.

xxviii. Tamuno, T. N. (1975). 'Herbert Macaulay; Nigerian Patriot' Heinemann, London. 
xxix. Turner, W. McCourt and D. Hulme (2013). The role of NGOs and civil society in development and poverty reduction Brooks World Poverty Institute, University of Manchester.

xxx. Vakil, A. C., 1997, 'Confronting the classification problem: toward a taxonomy of NGOs', World Development 25(12): 2057-2070.

xxxi. United Nation Development Programme (UNDP). (2019). Multidimensional Poverty in Nigerian. https://www.ng.undp.orgRetrieved 22/03/2021.

xxxii. UNDP/NBS (2017). National Multidimensional poverty Index for Nigeria. https://mppn.orgRetrieved $22 / 03 / 2021$.

xxxiii. United Nation Development Programme(2019). Inequality in Human Development in the $21^{\text {st }}$ Century. Briefing Note for Country on the 2019 Human Development Report.

xxxiv. United Nation Development Programme (1998). Human Development Report (HDR)

xxxv. World Bank (1990) World Bank Report: Poverty. DC: World Bank Group.

xxxvi. World Bank Technical Paper No 336 (African Series)

xxxvii. World Poverty Clock (2019). Nigeria as Poverty Capital of the World.

(https://www.worlddata.io.world.org)WashingtonRetrieved 22/03/2021. 